\title{
Layered double hydroxide nanocomposite for drug delivery systems; bio-distribution, toxicity and drug activity enhancement
}

\author{
Aminu Umar Kura ${ }^{1}$, Mohd Zobir Hussein ${ }^{3}$, Sharida Fakurazi ${ }^{1,2^{*}}$ and Palanisamy Arulselvan ${ }^{1}$
}

\begin{abstract}
The production of layered double hydroxide(LDH) nanocomposite as an alternative drug delivery system against various ailments is on the increase. Their toxicity potential is usually dose and time dependent with particle sizes, shapes and surface charge playing some role both in the in vitro and in vivo studies. The reticular endothelial system of especially the liver and spleen were shown to sequestrate most of these nanocomposite, especially those with sizes greater than $50 \mathrm{~nm}$. The intracellular drug delivery by these particles is mainly via endocytotic pathways aided by the surface charges in most cases. However, structural modification of these nanocomposite via coating using different types of material may lower the toxicity where present. More importantly, the coating may serve as targeting ligand hence, directing drug distribution and leading to proper drug delivery to specific area of need; it equally decreases the unwanted nanocomposite accumulation in especially the liver and spleen. These nanocomposite have the advantage of wider bio-distribution irrespective of route of administration, excellent targeted delivery potential with ease of synthetic modification including coating.
\end{abstract}

Keywords: Layered hydroxide, Bio-distribution, Cellular uptake, Toxicity, Drug activity enhancement

\section{Introduction}

Layered double hydroxide (LDH) nanocomposite is a class of inorganic material with chemical composition represented by the general formula, $\left[\mathrm{M}_{1-\mathrm{x}}^{2+} \mathrm{M}_{\mathrm{x}}^{3+}(\mathrm{OH})_{2}\right]^{\mathrm{x}+}$ $\left.\left[\mathrm{A}^{\mathrm{n}-}\right]_{\mathrm{x} / \mathrm{n}} \cdot \mathrm{mH}_{2} \mathrm{O}\right]$ where $\mathrm{M}^{2+}$ and $\mathrm{M}^{3+}$ are divalent and trivalent metal cations respectively [1]. The unique structure of LDH consisting of an outer positively charged metal hydroxide sheets and inner interlayer anions hydrated with water molecules aiding in its uptake and cellular penetration [1,2]. A controllable anion exchange that is $\mathrm{pH}$ dependent is possible due to the fascinating structure of LDH, which is also the basis of controlled-release properties of this carrier, making it a valuable choice for biological and pharmaceutical applications [3]. The synthesis and study of LDH have been on-going for decades [4]. In recent years, the synthetic production is on the increase due to their potential in electronics, drug/gene delivery,

\footnotetext{
* Correspondence: sharida@upm.edu.my

${ }^{1}$ Laboratory of Vaccines and Immunotherapeutics, Institute of Bioscience,

Selangor, Malaysia

2Department of Human Anatomy, Faculty of Medicine and Health Sciences,

Universiti Putra Malaysia, Selangor, Malaysia

Full list of author information is available at the end of the article
}

vaccine delivery system, diagnostic imaging among others [5]. In the field of biomedical application, different types of LDH were exploited for drug delivery, although they are still in the preliminary stage, but the results are promising and likely to join other delivery systems, that have reached an advanced level of clinical trials and use [6]. Some particularly interesting application of nanoparticles in general and LDH in particular includes alternative drug delivery system. This, resulted from their; local sustained release; high intrinsic pharmacological activity compared with conventional drugs. They also have improved the delivery of poorly water-soluble drugs, targeted delivery of drugs in a cell- or tissue-specific manner, transcytosis of drugs across tight epithelial and endothelial barriers (blood brain barrier inclusive), and delivery of large macromolecule drugs to intracellular sites of action [7-10]. Thus, the synthesis of LDH for drug delivery covered wide group of drugs, including but not limited to CNS diseases [7], cancers [8], anti-inflammatory and antibiotics [9] and imaging agents [10].

Below is a table (Table 1) that summarizes different type of layered double hydroxide nanocomposite synthesized

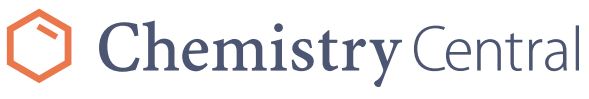


Table 1 Layered hydroxide nanocomposite toxicity and bio-distribution studies

\begin{tabular}{|c|c|c|c|c|c|c|c|}
\hline Nanocomposite type & Method of synthesis & Size (nm) & Concentration $(\mu \mathrm{g} / \mathrm{ml})$ & Assay (Test) & Cell type & Refrence & Remark \\
\hline 1. $\mathrm{Mg}-\mathrm{Al}-\mathrm{LDH}$ & $\begin{array}{l}\text { Co-precipitation/ion } \\
\text { exchange }\end{array}$ & $50-100$ & 40 & MTT & Human kidney $(\mathrm{N})$ & [4] & $\begin{array}{l}\text { Contain folic acid and not toxic, more than } \\
80 \% \text { of cell viable after } 3 \text { days. }\end{array}$ \\
\hline 2. Zn-Al-LDH & Co-precipitation & - & 150 & MTT & Mouse fibroblast (C) & [7] & $\begin{array}{l}\text { Higher fibroblast viability with LDH-levodopa } \\
\text { treatment than pure levodopa, LDH alone no } \\
\text { significant effect on fibroblast }\end{array}$ \\
\hline 3. ZLH & Direct method & - & 20 & MTT & $\begin{array}{l}\text { Human liver cell } \\
\text { (HepG2) }(\mathrm{C})\end{array}$ & {$[8]$} & $\begin{array}{l}\text { Hippuric acid (HA) intercalated ZLH showed } \\
\text { better synergy than pure HA and tamoxefen } \\
\text { on cancer cells. }\end{array}$ \\
\hline 4. Mg-Al-LDH & Co-precipitation & $150-200$ & 100 & MTT & Colon cell(C) & [10] & $\begin{array}{l}\text { LDH coated with chitosan also not toxic } \\
\text { at this dose on this cells }\end{array}$ \\
\hline 5. Mg-Al-LDH & Ion exchange & $>300$ & & Animal single dose & Whole animal & [13] & $\begin{array}{l}\text { Contain captopril and not toxic to the } \\
\text { animal exposed. }\end{array}$ \\
\hline 6. $\mathrm{Mg}-\mathrm{Al}-\mathrm{LDH}$ & Co-precipitation & $80-90$ & 20 & MTT & Human cervical cancer (C) & [16] & Potentiate the effect of paclitaxel \\
\hline 7. Mg-Al-LDH & Co-precipitation & $129-149$ & 100 & MTT/Trypan blue & Cortical neuron(N) & [17] & $\begin{array}{l}\text { DNA loaded LDH less toxic than pristine } \\
\text { LDH at higher dose }\end{array}$ \\
\hline 8. Mg-Al-LDH & Co-precipitation & - & 1000 & MTT & Human osteosarcoma (C) & [18] & $\begin{array}{l}\text { 5-fluorouraci loaded LDH show better } \\
\text { effect than free drugs }\end{array}$ \\
\hline 9. Mg-Al-LDH & Co-precipitation & $50,100,200,350$ & & MTT & Fibroblast(N) and lung(c) & {$[20]$} & $\begin{array}{l}\text { Potentiate the effect of anti-cancer and } \\
\text { milder on normal cells }\end{array}$ \\
\hline 10. Mg-Al-LDH/Zn-Al-LDH & Co-precipitation & - & $\begin{array}{l}80 \mathrm{mg} / \mathrm{kg} \text { of } \\
\text { ketoprofen }\end{array}$ & Magnifying lens & Mucosal surface & [21] & $\begin{array}{l}\text { Ketoprofen induced gastritis was reduced } \\
\text { with LDH intercalation }\end{array}$ \\
\hline 11. Mg-Al-LDH & Co-precipitation & - & $5-2000 \mathrm{mg} / \mathrm{kg}$ & Blood chemistry & Balb/c mice & [26] & $\begin{array}{l}\text { No significant changes to clinical and } \\
\text { biochemical parameters and no evidence } \\
\text { of particle retention in tissues. }\end{array}$ \\
\hline 12. Zn-Al-LDH & $\begin{array}{l}\text { Co-precipitation/ion } \\
\text { exchange }\end{array}$ & - & 1.2 & MTT & Chang liver cells (N) & [29] & $\begin{array}{l}\text { Lower concentration used and no effect on } \\
\text { viability from either the carrier or loaded LDH }\end{array}$ \\
\hline 13. ZLH & Direct method & - & 1000 & Trypan blue & Chang liver cells $(\mathrm{N})$ & {$[30]$} & $\begin{array}{l}\text { No Significant cell viability decrease below } \\
125 \mu \mathrm{g} / \mathrm{ml} \text { with good anti histamine release } \\
\text { from the intercalated cetirizine. }\end{array}$ \\
\hline 14. Zn-Al-LDH & Direct method & 150 & 800 & $\begin{array}{l}\text { MTT, GSH, ROS, } \\
\text { NO, comet assay, }\end{array}$ & Cervical cell (Hela) (C) & {$[32]$} & $\begin{array}{l}\text { Only dose above } 400 \mathrm{ug} / \mathrm{ml} \text { causes DNA } \\
\text { damages, hence biocompatibility possible } \\
\text { since it has no toxic } \\
\text { effect at lower doses base these assays. }\end{array}$ \\
\hline 15. Zn-Al-LDH & $\begin{array}{l}\text { Co-precipitation/ion } \\
\text { exchange }\end{array}$ & - & 50 & MTT & $\begin{array}{l}\text { Mouse fibroblast } \\
\text { and human lung } \\
\text { fibroblast cells }\end{array}$ & {$[33]$} & $\begin{array}{l}\text { The toxic effect of Para-amino salicylic acid } \\
\text { on the two cells was decrease after } \\
\text { intercalation into this LDH }\end{array}$ \\
\hline 16. Mg-Al-LDH & Co-precipitation & $50-300$ & 2000 & $\begin{array}{l}\text { Trypan blue } \\
\text { dye exclusion }\end{array}$ & $\begin{array}{l}\text { Human Embryonic } \\
\text { Kidney cell } \\
\text { (HEK 293T) (N) }\end{array}$ & [34] & $\begin{array}{l}\text { More than } 50 \% \text { of cells viable at } 500 \mu \mathrm{g} / \mathrm{ml} \text {. } \\
\text { DNA transfection successful but lower than } \\
\text { using commercial means. }\end{array}$ \\
\hline
\end{tabular}


Table 1 Layered hydroxide nanocomposite toxicity and bio-distribution studies (Continued)

\begin{tabular}{|c|c|c|c|c|c|c|c|}
\hline 17. Mg-Al-LDH & $\begin{array}{l}\text { Co-precipitation/ion } \\
\text { exchange }\end{array}$ & $57-63$ & 40 & MTT & $\begin{array}{l}\text { Human gastric epithelial cell } \\
\text { (GES-1) gastric cancer cell } \\
\text { (MKN45 and SGC-7901) }\end{array}$ & {$[36]$} & $\begin{array}{l}\text { Etoposide harmful effect on normal cell } \\
\text { significantly reduced and its anticancer effec } \\
\text { enhanced after intercalation into LDH. }\end{array}$ \\
\hline 18. Mg-Al-LDH & Co-precipitation & - & 50 & MTT & $\begin{array}{l}\text { Breast (MCF-7) (C), cervical } \\
\text { (HeLa) (C), and fibroblast } \\
(3 T 3)(N)\end{array}$ & {$[37]$} & $\begin{array}{l}\text { Not toxic to all the three cell line, but } \\
\text { enhanced the anti-cancer effect of } \\
\text { protocatechuic acid. }\end{array}$ \\
\hline 19. Mg-Al-LDH & Co-precipitation & 20 & 50 & MTT & lung fibroblast cell (N) & {$[38]$} & $\begin{array}{l}\text { No toxic effect against the tested cells } \\
\text { and bacteria. Activity of the intercalated } \\
\text { antibiotics similar to the naked one }\end{array}$ \\
\hline
\end{tabular}

The table summarises some of the layered hydroxide nanocomposite activity in relation to toxicity and distribution over the last few years. The majority of whom were synthesis by either co-precipitation or ion exchange method, with sizes between 50-300 nm in most of them. Cell proliferation assay using MTT is applied in large no of the studies to evaluate for their cytotoxic and or anti-cancer impact on some selected cell lines. 
by co-precipitation or ion exchange method, sizes in nanometre, type of test conducted and their outcome in relation to toxicity or drug enhancement especially against cancers.

Several methods have been used for LDH synthesis, among which are the co-precipitation, ion exchange, urea hydrolysis, structural reconstruction and sol-gel methods [1]. Differences in method of synthesis affect not only the crystalline nature of the particles, but also the loading capacity and quantity produced [4]. Folic acid intercalated into a magnesium aluminium hybrid via Co precipitation and ion-exchange method demonstrated 19 and $17 \%$ loading of the drug respectively [4]. Manoeuvres like sonication, hydrothermal treatment and microwave irridation usage during aging demonstrated changes to the morphology of particles [1]. However, in a drug delivery system study, most researchers demonstrated good and successful intercalation of different drugs into either zinc- aluminium or magnesium aluminium based LDH using Co precipitation and or ion-exchange methods [11,12]. The emergence of Nanomedicine is of outmost importance in the health system, more so in the area of drug delivery. Over the last few decades, several of such delivery systems have been synthesized and tested, few of which have made it to commercial stage [13]. Layered double hydroxide in particular is regarded as one of those with the least toxicity among the inorganic types [14]. They are relatively easy to synthesize in the laboratory, with different controllable sizes, shapes and other related features $[1,2,4]$. No single parameter has yet been identified as the one being responsible for most nanoparticles toxicity, LDH inclusive $[15,16]$, but many physicochemical parameters have been proposed to be critical determinants in nanomaterial toxicity, among which are; crystalline structure, surface area, oxidation status, size and chemical composition of the nanoparticle $[15,16]$. This review aims at discussing LDH in delivery of drugs with emphasis on wider distribution potential, organized cellular uptake mechanism, drug enhancement activity especially, anti-cancers and their characteristics decrease toxicity potential in drug delivery when compared to pure drugs.

\section{Review}

\section{Bio-distribution and cellular uptake}

Decade's back, passive diffusion was shown to be the main mechanism in drug transport across biological barriers, it is a key determinant in pharmacokinetics [17]. Later studies showed carrier mediated process in drug transport across the biological membrane also played major roles, adding to the existing passive mechanism [17]. The two processes are vital in drug transport to areas of interest irrespective of admission route. In the case of $\mathrm{LDH}$, the positively charged outer sheet of the delivery system is attracted by a negatively charged cell membrane, enables a facile penetration of LDH into cells [5]. A study was done previously to show the impact of surface charge on $\mathrm{LDH}$ and the mechanism of its cellular uptake [18]. There, a fluorescence and transmission electron microscope (TEM) were applied, to demonstrate the endocytotic cell entrance of paclitaxel-LDH nanoparticles bounded with an antibody called fluorescein isothiocyanate (FITC) into cervical cancer cells (Hela) [18]. The positive charge outer layer of $\mathrm{LDH}$ whose zeta potential is $20.3 \mathrm{mV}$ aided in the uptake and cell penetration [18]. In order to identify the specific endocytotic pathway for LDH entrance into the cells, the researchers blocked the clathrin and caveolin-mediated (endocythotic receptors) pathways using chlorpromazine and nystatin (inhibitors) respectively on a neuronal cell. With a chlorpromazine blockage, there was no vesicle formation following treatment with $\mathrm{LDH}$, but no effect clearly shown with nystatin treatment $[19,20]$. An anti-cancer loaded LDH was shown to enter a cervical cancer cell via the above mentioned clathrin-mediated endocytosis also [21]. The study further excluded caveolae-mediated endocytosis of the methotrexate loaded LDH into the cancer cells [21]. Some accessory cellular protein studies were used to prove the inclusion of the former and exclusion of the latter mechanism [21]. Hence, LDH cellular uptake and penetration is via endocytosis and mainly through clathrinmediated pathways.

Further influence in LDH particle uptake is the particle size and shapes, with sizes between 50-200 nm showing concentration dependent uptake, while sizes $350 \mathrm{~nm}$ and above not concentration dependent [5]. Both hexagonal and rod shape LDH nanocomposite entered the cells through the same endocytotic pathway; however the hexagonal shaped particle was found to be distributed within the nucleus of the cells [5]. The prettiness of such findings is to do with possible usage of $\mathrm{LDH}$ in gene delivery to the nucleus in gene therapy and other related gene application. These results suggested further, the promising drug delivery potential of LDH at the cellular level without necessary damaging cell structure. Further research on synthesis and applications should focus on the size and shape specific LDH production in order to improve their actual medical application especially in areas of drug delivery.

The distribution of layered double hydroxide nanocomposite is not much different from the rest of nanoparticles, reticular endothelial system (RES) takes larger amount, especially the liver, kidney, spleen and lungs [5]. The sizes of the particle play significant role in determining the particle distribution [5]. Particles less than $5 \mathrm{~nm}$ are easily removed by the renal clearance; sizes more than $100 \mathrm{~nm}$, are mostly sequestrated by the RES of the liver, lungs, kidney and spleen [5]. Intra-peritoneal administration of LDH to mice for five days with sizes $100-200 \mathrm{~nm}$ showed a 
higher distribution to the liver, lung, spleen and kidney, but not brain and/or heart [22]. Both zinc and aluminium based LDH revealed good plasma distribution of nonsteroidal anti-inflammatory drug (NSAID) after oral ingestion and the analgesic effectiveness is almost similar to its counterpart (pure NSAID), added with advantage of increase gastric tolerability [23]. LDH containing antibiotics as a local drug delivery system also showed promising result [24]. This was made possible due to likelihood of sustained release and low toxicity properties of this noble carrier leading to a good drug delivery to infected middle ear in the presence of prosthesis. More recently, an in vivo study conducted by a group of scientist showed the distribution of LDH to liver, lung and spleen following an intravenous tail vein injection [10]. This same LDH carrier showed preference to the lung when coated with Chitosan. Further increase Chitosan concentration (higher concentration) leads to accumulation in liver and avoided the lung [10]. This preferential in vivo bio-distribution of LDH following modification of coating substance opened a high potential for developing organ-specific drug-delivery systems using this noble carrier both in diagnosis and therapy. In general, findings of wider distribution via different routes of administration within the range of $50-250 \mathrm{~nm}$ are further adding to the merits of $\mathrm{LDH}$ in drug delivery potential. However, more needs to be done, especially, the role of different coating material and active targeting in delivering LDH to specific areas of interest.

Invasion of brain tissue by exogenous substances/pathogens (drugs and microorganism) are strongly prevented by the blood-brain barrier (BBB) [24]. The BBB serves as a gate in preventing dangerous substances from entering the central nervous system (CNS), however, in doing so other important substances, including drugs for treating CNS pathologies like Parkinson's disease, Alzheimer, infections and tumors are equally prevented [24,25]. Amidst these difficulties some inorganic nanoparticles of iron oxide (ION) were able to reach the brain in significant concentrations in experimental animals [26]. The same type of nanoparticle (ION) showed over $80 \%$ uptake of Amyloid beta $(A \beta)$ in the presence of intact and un-inflamed BBB in rats [27]. LDH nanocomposite of magnesium aluminium had equally exhibited good plasma distribution after oral ingestion; it was distributed to most of the body organs, including brain even though not statistically different from control tissue samples [28]. The particle size was found to be around $100 \mathrm{~nm}$, and the size is likely a part that makes it possible in achieving wider distribution of most organs, including the brain without being sequestrated by the RES [5].

Drug delivery to the brain is another emerging area in Nanomedicine [27-29]. Several surfactants have been considered in coating nanoparticle for drug delivery to the brain [29]. Nevertheless, Tween-80 coated nanoparticles enhanced transport to brain than most surfactant used [29]. Nanoparticles from copper $(\mathrm{Cu})$, aluminium (Al) and silver $(\mathrm{Ag})$ with size range 50 to $60 \mathrm{~nm}$ suspended in Tween-80 and administered parentally to experimental animal showed good brain permeation [30]. These and other related findings can be considered in future studies using LDH for drug delivery to the brain. The brain delivery of different types of the nanoparticles using Tween- 80 coating is considered by some scientist to be a 'gold standard' [29].

\section{Decrease toxicity and drug activity enhancement}

Layered double hydroxide nanocomposite is now emerging as potential new drug delivery system due to its low toxicity and higher biocompatibility [18,31]. Some studies have shown LDH to have the same or lower toxicity than the corresponding pure drug it carries when tested on normal cell lines [18,31]. Among which was the investigation of toxicity effects on Chang cells line, a normal liver cell using trypan blue exclusion assay at various concentrations of zinc layered hydroxide (ZLH) and cetirizine nanocomposite (CETN) [32]. CETN was found to have an $\mathrm{IC}_{50}$ of $617 \mu \mathrm{g} / \mathrm{mL}$, whereas the ZLH showed decrease cytotoxicity with $\mathrm{IC}_{50}$ values of $670 \mu \mathrm{g} / \mathrm{ml}$ [32]. Perindopril (PE), an anti-hypertensive agent showed a similar toxicity effect on Chang cells compared to the corresponding nanocomposite intercalated with PE [31]. The synthesis was done by ion exchange and co-precipitation methods [31]. The controlled, sustained and $\mathrm{pH}$ dependent release property of LDH is making it biocompatible to most tissues, cell and animals as a whole. As exciting as the toxicity evaluation results of most synthesized LDH are, their application especially in drug delivery may be hindered by lack of standardization of physicochemical parameters. Among the critical considerations often missing are differences in sizes, surfaces charges and particle solubility, which may lead to results misinterpretation especially where comparism are made [33]. Nanoparticle exposure to physiological fluids is another factor that may alter the physicochemical properties leading to aggregate or agglomerate formation and possible toxicity [33].

Nevertheless, the toxicity potential of many drugs were significantly reduced after intercalation into either zinc or magnesium nanocomposite. Drug efficacies including anticancer potential were on the increase due to intercalation in LDH nanocomposite, it was achieved alongside decreasing unwanted anti-cancer side effect on normal cells $[18,34]$. Most body organs, including the brain were accessible by LDH nanocomposite to deliver different types of drug, achievable, especially with those particles whose sizes are less than $250 \mathrm{~nm}$ [28]. Where specific area is the target for particular drug delivery coating with various agents are yielding amazing results [10]. 
LDH as a drug delivery system has gone beyond decreasing toxicity of parent compound, but also potentiation of the desired effect, both in vitro and in vivo model [18]. For example, Podophyllotoxin, is an agent with poor water solubility and low bioavailability. These two negative attributes have limited the success of Podophyllotoxin in cancer treatment [18]. However, the anti-cancer activity improved following intercalation onto this nanodelivery system [18]. A time-dependent decrease in cervical cancer cells (Hela) viability seen with exposure to $20 \mu \mathrm{g} / \mathrm{ml}$ of paclitaxel (PPT) and its corresponding LDH nanocomposite [18]. The LDH nanocomposite showed higher toxicity (anticancer) effect than pure PPT [18]. This positive outcome is due to better cell penetration of the new delivery system, controlled and sustain release ability, increase stability of the active compound while inside the carrier. LDH itself had no significant effect on the cancer cells [18]. Other cancers where LDH's resulted in an improved anti-cancer activity are liver carcinoma cell line (HepG2) [8]. This cancer was treated with tamoxifen alone and then followed by a mixture of either hippuric acid or its nanocomposite (HAN). This was done to study the synergistic effect of hippuric acid on liver cancer. The anti-cancer effect of tamoxifen increased about 2-fold when HepG2 cells were co-treated with HAN, whereas co-treatment with pure hippuric acid did not increase the toxicity. This shows improved anti-cancer activity as a result of synergy and believed to be secondary to HAN permeation across the cell membrane much more effectively than hippuric acid alone [8]. MTT assay for cell viability also demonstrated folic-acid-LDH complex to have better ability in reducing cancer cell viability $(\mathrm{p}<0.01)$ compared to folic acid alone [34].

However, one thing in common to most LDH nanocomposite is, toxicity reduction compared to the pure drugs intercalated in them. They also demonstrated a good anticancer effect, even better than their corresponding pure drugs. The readily controllable sizes, plus cell's attraction potentials of the LDH particle played role in cellular distribution and uptake. They equally play vital roles in decreasing toxicity and enhancing anti-cancer effects [35]. LDH produces some tissues and cells friendlily by-products $\left(\mathrm{H}_{2} \mathrm{O}, \mathrm{Mg}^{2+}, \mathrm{Al}^{3+}, \mathrm{Zn}^{2+}\right)$ under physiological conditions ( $\mathrm{pH}=7.4$ or less) [35]. This can cushion the acidification tendencies in endosomes and lysosome of cells after the nanocomposite uptake [35]. Thus, toxicity secondary to high acidity will be reduced. Recently, we reported a sustained, controlled, slow and $\mathrm{pH}$ dependent release of levodopa from zinc aluminium nanocomposite that lasted three-six days [7]. This slow releasing property of toxic compounds from the interlayer sheet of $\mathrm{LDH}$ over time is also a factor in suppressing drug toxicity.

Coating LDH with either polymers or surfactants have a role to play on the toxicity, for example coating, zinc aluminium LDH with Tween-80 further decrease its toxicity on neural cells [36]. Better dispersion due to coating may be responsible for the decrease toxicity noted in that study, other "improved" physiochemical characteristics in the coated nanomaterial are likely additional reasons. Introduction of coating affect the characters of nanoparticles like their surface charges, thermal stability, crystalline morphology, cellular/tissue uptake, target and ultimately toxicity profile in both tissue and animal exposure studies [36,37]. A related metal oxide nanoparticle (iron oxide) was coated with dextran and polymer polyethylene glycol (PEG) in another study [36]. The coated nanoparticle demonstrated decrease toxicity on the tested cells compared to their corresponding uncoated nanoparticles [38].

Microorganisms, including some bacteria are part of the human system, called normal microbial flora, they usually live in the mucous membranes and on the skin. They aid in digestion, defend the body against harmful organisms and help the immune system to mature, as such they are considered medically beneficial [39]. Antibiotics or drug delivery vehicle not capable of discriminating between the beneficial and harmful microorganism may be dangerous to human. Both Gram-positive (S. aureus) and Gramnegative (E. coli) bacterial growth was not inhibited by LDH usage as drug delivery agent at $250 \mu \mathrm{g} / \mathrm{ml}$ [40]. However, it successfully delivered anti-microbial silver nanoparticles that inhibit the growth of microbes [40]. This inorganic nanohybrid material allows for an efficient delivery and interaction between silver nanoparticle (antibiotic) and bacteria. It provides a flat form for possible better drug delivery potential against pathogenic organism in a sustain release fashion, without necessarily harming the medically important organism in the body in future.

In vivo toxicity assessment of $\mathrm{LDH}$ was studied via a modified Spearman-Karber statistic method called the Trimmed Spearman Karber method, in which orally administered captopril; LDH and LDH-captopril in SpragueDawley rats were found to have LD50 of $6590 \mathrm{mg} / \mathrm{kg}$, $7410 \mathrm{mg} / \mathrm{kg}$ and $7315 \mathrm{mg} / \mathrm{kg}$ respectively [41]. Both LDH and LDH-captopril can be considered as relatively safe since they have LD50 that lies between $5000-15,000 \mathrm{mg} / \mathrm{kg}$ after oral dosing $[41,42]$. Some interesting recent advances in $\mathrm{LDH}$ usage as drug delivery include their use as a delivery vehicle for anti-cancer in animal study $[2,43]$. Methotrexate was intercalated into LDH and its anti-cancer efficacy tested. The new delivery system showed improved anti-cancer efficacy than pure methotrexate, better distribution potential and much lower toxicity in the tested animals [43]. Some of the materials used in LDH were classified medically as heavy metals with possible consequences [13,44]. Zinc for example, is a trace element needed by the body as cofactor for some enzymatic reaction [45], while aluminium is used 
therapeutically in medicine [46]. Malicious effects may ensure from any of these elements if taken in certain quantity or taken in the presence of altered physiology, a good example of which is in aluminium toxicity in chronic renal disease patients or in the elderly [47-49]. Other elements used in LDH synthesis poses different toxicity profiles when their chemical structure changes from stable element to free radical with oxidative potentials $[50,51]$.

\section{Conclusion}

However, no standard size, shape or coating has been set to assess the potential of this delivery vehicle in drug delivery. Different researchers use different sizes, concentration, shapes, tissue, cells, animals and even methodology in LDH assessment. Limited studies done to assess this noble carrier for chronic toxicity. Thus difficult or even impossible to make a generalize conclusion with regard to toxicity, distribution or drug enhancement ability. Another aspect in need of extensive research in the area of LDH nanocomposite for drug delivery is the chemical transformation tendencies of the parent metal in the body leading to free radical generation. LDH had proved to be promising in the area of drug delivery, especially in the areas of cancer therapy and MRI procedure. This nanodelivery system used either an already existing drug/compound or new drug/ compound making them more efficient against various disorders/diseases and or less toxic. Though, nanoparticles size play a vital role in tissue distribution, but biodistribution potential of these noble carriers is significantly influenced by surface coating. Some coating substances act as a targeting agent with specific delivery potential overriding the limitation caused by the particle size. The toxicity profile of this delivery system can be acceptable, as modification in size, shape, coating and functionalization could be applied to manipulate the toxicity potential where present. Generally, low toxicity and higher biocompatibility are virtues associated with LDH nanomaterial, and it is now emerging as a potential new drug delivery system. Cellular uptake of these carriers is usually coordinated; receptor mediated and energy dependent processes. As an alternative drug delivery vehicle layered hydroxide nanocomposite of both zinc and magnesium nitrate containing different chemotherapeutic agent have positively enhanced anticancer activity of so many cancer cells. They were also shown to decrease the possible cytotoxic effect of the active agents on most cell lines tested. On their own they had no anticancer or antibiotic effects, but as delivery vehicles they are yielding welcomed pharmacokinetics results. Wider bio-distribution, decreases toxicity potential, enhanced efficacy and targeted delivery will be the basis for continued usage of this nanocomposite in drug delivery system in the future.

\section{Abbreviations}

LDH: Layered double hydroxide; MRI: Magnetic resonance image; RES: Reticular endothelial system; CNS: Central nervous system; TEM: Transmission electron microscopy; NSAIDs: Nonsteroidal anti-inflammatory drugs; BBB: Blood brain barrier; CETN: Cetirizine nanocomposite; ZLH: Zinc layered hydroxide; PE: Perindopril erbumine; ION: Iron oxide nanoparticle; MTT: 3-(4,5dimethylthiazol-2-yl) -2,5-diphenyltetrazolium bromide; PPT: Paclitaxel; HAN: Hippuric acid nanocomposite; LD L : Lethal dose 50; PASA: Para-amino salicylic acid; SZNs: Salicylate-zinc layered hydroxide nanohybrids; ZnO: Zinc oxide; GSH: Glutathione assay; ROS: Reactive oxygen specie; NO: Nitric oxide assay; FITC: Fluorescein isothiocyanate.

\section{Competing interests}

The authors declare that they have no competing interests.

\section{Authors' contributions}

AUK performed the data gathering and the initial write-up, SF, MZH and AP were involved drafting the manuscript, intellectual revision and gave approval for the final manuscript.

\section{Acknowledgements}

We would like to thank Universiti Putra Malaysia and Ministry of Science, Technology, and Innovation Malaysia for most of our project funding under UPM grant and nanofund NND/NA/(I) TD11-010. VOT No 5489101 and 9399845.

\section{Author details}

'Laboratory of Vaccines and Immunotherapeutics, Institute of Bioscience, Selangor, Malaysia. ${ }^{2}$ Department of Human Anatomy, Faculty of Medicine and Health Sciences, Universiti Putra Malaysia, Selangor, Malaysia. ${ }^{3}$ Materials Synthesis and Characterization Laboratory, Institute of Advanced Technology, Universiti Putra Malaysia, Serdang, Selangor 43400 UPM, Malaysia.

Received: 24 March 2014 Accepted: 21 July 2014

Published: 10 August 2014

\section{References}

1. Wang $\mathrm{Q}, \mathrm{O}$ 'Hare D: Recent advances in the synthesis and application of Layered Double Hydroxide (LDH) nano-sheets. Chem Rev 2012, 112:4124-4155.

2. Choi S-J, Oh J-M, Choy J-H: Biocompatible Nanoparticles Intercalated with Anticancer Drug for Target Delivery:Pharmacokinetic and Biodistribution Study. J Nanosci Nanotechnol 2010, 10:2913-2916.

3. Kovanda F, Jindová E, Doušová B, Koloušek D, Pleštil J, Sedláková Z: Layered double hydroxides intercalated with organic anions and their application in preparation of Idh/polymer nanocomposites. Acta geodynamica et geomaterialia 2009, 6, No. 1(153):111-119.

4. Qin L, Wang S, Zhang R, Zhu R, Sun X, Yao S: Two different approaches to synthesizing Mg-Al-layered double hydroxides as folic acid carriers. J Phys Chem Solids 2008, 69:2779-2784.

5. Choi S-J, Choy J-H: Layered double hydroxide nanoparticles as target-specific delivery carriers: uptake mechanism and toxicity. Nanomedicine 2011, 6(5):803-814.

6. Raj Kumar D, Saurabh S: Development of oxaliplatinencapsulated in magnetic nanocarriers of pectin as a potential targeted drug delivery for cancer therapy. Results Pharma Sci 2012, 2:38-45.

7. Aminu Umar K, Samer Hasan Hussein Al A, Mohd Zobir H, Sharida F, Palanisamy A: Development of a controlled-release anti-parkinsonian nanodelivery system using levodopa as the active agent. Int $J$ Nanomedicine 2013, 8:1103-1110.

8. Samer Hasan Hussein Al A, Mothanna A-Q, Mohd Zobir H, Zulkarnain Z, Muhammad Nazrul H: Preparation of hippurate-zinc layered hydroxide nanohybrid and its synergistic effect with tamoxifen on HepG2 cell lines. Int J Nanomedicine 2011, 6:3099-3111.

9. Bullo S, Mohd Zobir H, Samer Hasan H-A-A, Palanisamy A, Sharida F: Sustained release formulation of an anti-tuberculosis drug based on para-amino salicylic acid-zinc layered hydroxide nanocomposite. Chem Cent J 2013, 7:72

10. Wei P-R, Cheng S-H, Liao W-N, Kao K-C, Weng C-F, Lee C-H: Synthesis of chitosan-coated near-infrared layered double hydroxide nanoparticles for in vivo optical imaging. J Mater Chem 2012, 22:5503-5513.

11. Zou N, Plank J: Intercalation of papain enzyme into hydrotalcite type layered double hydroxide. J Phys Chem Solids 2012, 73:1127-1130. 
12. Salata OV: Applications of nanoparticles in biology and medicine. J Nanobiotechnol 2004, 2:3.

13. Kofi A, Dickson RA, Amponsah IK, Nooni IK: The heavy metal contents of some selected medicinal plants sampled from different geographical locations. Pharmacognosy Res 2013, 5(2):103-108.

14. Alexa F, Popovici RF, Ignat M, Popovici E, Voicu VA: Non-toxic nanocomposite containing captopril intercalated into green inorganic carrier. Dig J Nanomater Biostructures 2011, 6(3):1091-1101.

15. Catarina Pinto R, Neufeld RJ, Ribeiro AJ, Francisco V, Nanoencapsulation I: Methods for preparation of drug-loaded polymeric nanoparticles Nanomedicine. Nanotechnol Biol Med 2006, 2:8-21.

16. Olivier J-C: Drug transport to brain with targeted nanoparticles. J Am SoC Exp NeuroTherapeutics 2005, 2(1):108-119.

17. Qina L, Xuea M, Wanga W, Zhua R, Wanga S, Sunb J, Zhangc R, Suna X: The in vitro and in vivo anti-tumor effect of layered double hydroxides nanoparticles as delivery for podophyllotoxin. Int J Pharm 2010, 388:223-230.

18. Sugano K, Kansy M, Artursson P, Avdeef A, Bendels S, Di L, Ecker GF, Faller B, Fischer $H$, Gerebtzoff $G$, Lennernaes $H$, Senner F: Coexistence of passive and carrier-mediated processes in drug transport. Nat Rev Drug Discov 2010, 9:597-614

19. Wong Y, Markham K, Zhi Ping X, Min C, Lu GQM, Bartlett PF, Cooper HM: Efficient delivery of siRNA to cortical neurons using layered double hydroxide Nanoparticles. Biomaterials 2010, 31(33):8770-8779.

20. Choi S-J, Jae-Min O, Choy J-H: Biocompatible Nanoparticles Intercalated with Anticancer Drug for Target Delivery: Pharmacokinetic and Biodistribution Study. J Nanosci Nanotechnol 2010, 10:2913-2916.

21. Jae-Min O, Choi S-J, Kim S-T, Choy J-H: Cellular uptake mechanism of an inorganic nanovehicle and its drug conjugates: enhanced efficacy due to clathrin-mediated endocytosis. Bioconjugate Chem 2006, 17(6):1411-1417.

22. Soo Jin C, Jae-Min OH, Jin-HO C: Biocompatible ceramic nanocarriers for drug delivery with high efficiency. J Ceram Soc Jpn 2009, 117(5):543-549.

23. Mihaela S, Doina H, Jaba IM, Bogdan T, Dunarea I, Mungiu OC, lonel Marcel P: In vitro and in vivo behavior of ketoprofen intercalatedinto layered double hydroxides. J Mater Sci Mater Med 2010, 21:3009-3018.

24. Sonu B, Furong T, Tobias S, Wolfgang K, de la Fuente JM, Valeria G, Paul B, Giovani E, Vasilis N, Daniel R: Multifunctional Nanocarriers for diagnostics, drug delivery and targeted treatment across blood-brain barrier: perspectives on tracking and neuroimaging. Part Fibre Toxicol 2010, 7:3

25. Pardridge WM: Drug transport across the blood-brain barrier. J Cereb Blood Flow Metab 2012, 32:1959-1972.

26. Wang J, Chen Y, Chen B, Ding J, Xia G, Gao C, Cheng J, Jin N, Zhou Y, Li X, Tang M, Xue Mei W: Pharmacokinetic parameters and tissue distribution of magnetic $\mathrm{Fe}_{3} \mathrm{O}_{4}$ nanoparticles in mice. Int J Nanomedicine 2010, 5:861-866.

27. Amir Reza J, Seyyedeh Leila H-S, Morteza M, Hassan Y, Majdabadi A, Majid P: Preparation and biological evaluation of radiolabeled-folate embedded superparamagnetic nanoparticles in wild-type rats. J Radioanal NuCl Chem 2011, 287:119-127

28. Jin Y, Hea-Eun C, Soo-Jin C: Acute oral toxicity and kinetic behaviors of inorganic layered nanoparticles. J Nanomater 2013, 2013(Article ID 628381):8.

29. Wohlfart S, Gelperina S, Kreuter J: Transport of drugs across the blood-brain barrier by nanoparticles. J Control Release 2012, 161(2):264-273.

30. Hari Shanker S, Saber H, John S, Ali SF, Aruna S: Influence of Nanoparticles on Blood-Brain Barrier Permeability and Brain Edema Formation in Rats. Acta Neurochir Suppl 2010, 106:359-364.

31. Samer Hasan Hussein Al A, Mothanna A-Q, Mohd Zobir H, Maznah I, Zulkarnain Z, Muhammad Nazrul H: Controlled release and angiotensin-converting enzyme inhibition properties of an antihypertensive drug based on a perindopril erbumine-layered double hydroxide nanocomposite. Int $\mathrm{J}$ Nanomedicine 2012, 7:2129-2141.

32. Samer Hasan Hussein Al A, Mothanna A-Q, Mohd Zobir H, Maznah I, Zulkarnain Z, Muhammad Nazrul H: Controlled-release formulation of antihistamine based on cetirizine zinc-layered hydroxide nanocomposites and its effect on histamine release from basophilic leukemia (RBL-2H3) cells. Int J Nanomedicine 2012, 7:3351-3363.

33. Soo-Jin C, Jong Kwon L, Jayoung J, Jin-Ho C: Toxicity evaluation of inorganic nanoparticles: considerationsand challenges. Mol Cell Toxicol 2013, 9:205-210.

34. Zhi Ping X, Lu GQM: Layered double hydroxide nanomaterials as potential cellular drug delivery agents. Pure Appl Chem 2006, 78(9):1771-1779.
35. Saifullah B, Mohd Zobir H, Samer Hasan H-A-A, Palanisamy A, Sharida F: Antituberculosis nanodelivery system with controlled-release properties based on para-amino salicylate-zinc aluminum-layered double-hydroxide nanocomposites. Drug Des Dev Ther 2013, 7:1365-1375.

36. Aminu Umar K, Samer Hasan H-A-A, Mohd Zobir H, Sharida F: Preparation of tween 80-Zn/Al-Levodopa-Layered double hydroxides nanocomposite for drug delivery system. Sci World J 2014, 2014(Article ID 104246):10.

37. David Z, Benjamin S, Sanjay M, Christina G: Improved Stability of "Naked" Gold Nanoparticles Enabled by in Situ Coating with Mono and Multivalent Thiol PEG Ligands. Langmuir 2013, 29(36):11217-11226.

38. Yu M, Huang S, Yu K, Clyne AM: Dextran and polymer polyethylene glycol (PEG) coating reduce both 5 and $30 \mathrm{~nm}$ iron oxide nanoparticle cytotoxicity in 2D and 3D cell culture. Int J Mol Sci 2012, 13(5):5554-5570.

39. Giedraitienè A, Vitkauskienè A, Naginienè R, Pavilonis A: Antibiotic resistance mechanisms of clinically important bacteria. Medicina (Kaunas) 2011, 47(3):137-146.

40. Marcato PD, Parizotto NV, Martinez DST, Paula AJ, Ferreira IR, Melo PS, Durán N, AJ Braz OL: New hybrid material based on layered double hydroxides and biogenic silver nanoparticles. J Braz Chem Soc 2013, 24(2):266-272.

41. Hamilton M, Russo R, Thurston ANDR: Trimmed Spearman-Karber Method For Estimating Median Lethal Concentrations In Toxicity Bioassays. In Washington, D.C: U.S. Environmental Protection Agency; 1977. EPA/600/ J-77/178 (NTIS PB81191918).

42. Hodge HC, Sterner JH: Tabulation of toxicity classes. Am Ind Hyg Assoc Q 1949, 10(4):93-96.

43. Sparreboom A, Baker SD, Verweij J: Paclitaxel repackaged in an albumin-stabilized nanoparticle: handy or just a dandy? J Clin Oncol 2005, 23(31):7765-7767.

44. Li F, Jin L, Han J, Wei M, Li C: Synthesis and controlled release properties of prednisone intercalated $\mathrm{Mg}$-Al layered double hydroxide composite. Ind Eng Chem Res 2009, 48:5590-5597.

45. Deshpande JD, Joshi MM, Giri PA: Zinc: The trace element of major importance in human nutrition and health. Int J Med Sci Public Health 2013, 2(1):1-6

46. Zajac P, Holbrook A, Super ME, Vogt M: An overview: current clinical guidelines for the evaluation, diagnosis, treatment, and management of dyspepsia. Osteopath Fam Phys 2013, 5(2):79-85.

47. Seng Yue C, Christie M, Lavergne V, Sikaneta T, Taskapan H, Mardini K, Tam P, Ting R, Ghannoum M: Aluminum toxicokinetics in peritoneal dialysis patients. Clin Toxicol 2011, 49(7):659-663.

48. Proudfoot AT: Aluminium and zinc phosphide poisoning. Clin Toxicol (Phila) 2009, 47(2):89-100. Review.

49. Brown RO, Morgan LM, Bhattacharya SK, Johnson PL, Minard G, Dickerson RN: Potential aluminum exposure from parenteral nutrition in patients with acute kidney injury. Ann Pharmacother 2008, 42(10):1410-1415.

50. Al Kahtani MA, Abdel-Moneim AM, El-Sayed WM: The influence of taurine pretreatment on aluminum chloride induced nephrotoxicity in Swiss albino mice. Histol Histopathol 2014, 29(1):45-55.

51. Vučetić-Arsić S, Radonjić NV, Jovanović M, Selaković V, Nikolić T, Velimirović M, Stojković T, Milovanović A, Milovanović J, Petronijević ND: Oxidative stress precedes mitochondrial dysfunction in gerbil brain after aluminum ingestion. Environ Toxicol Pharmacol 2013, 36(3):1242-1252

doi:10.1186/s13065-014-0047-2

Cite this article as: Kura et al:: Layered double hydroxide

nanocomposite for drug delivery systems; bio-distribution, toxicity and drug activity enhancement. Chemistry Central Journal 2014 8:47. 